\title{
Frederic E. Wakeman Jr., Telling Chinese History: A Selection of Essays
}

\section{Guannan Li}

\section{(2) OpenEdition}

\section{Journals}

Édition électronique

URL : http://journals.openedition.org/chinaperspectives/5352

DOI : 10.4000/chinaperspectives.5352

ISSN : 1996-4617

Éditeur

Centre d'étude français sur la Chine contemporaine

Édition imprimée

Date de publication : 15 décembre 2010

ISSN : 2070-3449

Référence électronique

Guannan Li, «Frederic E. Wakeman Jr., Telling Chinese History: A Selection of Essays », China

Perspectives [En ligne], 2010/4 | 2010, mis en ligne le 15 décembre 2010, consulté le 10 décembre 2020. URL : http://journals.openedition.org/chinaperspectives/5352 ; DOI : https://doi.org/10.4000/ chinaperspectives.5352

Ce document a été généré automatiquement le 10 décembre 2020.

(c) All rights reserved 


\title{
Frederic E. Wakeman Jr., Telling Chinese History: A Selection of Essays
}

\author{
Guannan Li
}

Frederic E. Wakeman Jr., Telling Chinese History: A Selection of Essays, Selected and Edited by Lea H. Wakeman, Berkeley, University of California Press, 2009, 480 pp.

2This posthumous publication brings together 15 articles by Frederic Wakeman that were produced over the four decades of his academic life. The volume covers a wide range of topics, offering a comprehensive portrayal of Wakeman's career. It includes essays that contributed to Wakeman's career as a historian of the Ming-Qing transition (Part Two), a pioneering researcher of Kuomintang efforts at policing Shanghai during the Republican period (Part Three), and an analyst of the relationships between the Chinese state and society (Part Five). It also sheds light on Wakeman's global outlook in the writing of Chinese history (Introduction and Part I), his involvement with the transformation of the historiography of modern China (Part Four), and finally, his advocacy of the value of historical narrative (Chapter 14: Reflection).

3In the first part of the book, an introductory essay by the distinguished sociologist S. N. Eisenstadt, "China in the Context of World History," challenges Wakeman's image as a China-centred historian by connecting his scholarship to a recent orientation within the modern china field that aims to reconsider the boundaries of Chineseness from the perspective of world history. Wakeman's own piece, "China and the Seventeenth-Century World Crisis," examines the severe consequences of the global depression from 1620 to 1640 that damaged the Ming Dynasty's monetary system. Wakeman argues that late Ming economic difficulties were caused by the fluctuating world trading system that led to a systemic breakdown affecting its entire political and social order. Among these global causes and local effects, Wakeman identifies a strong connection between the extensive levels of official embezzlement and the inflationary trends of the late Ming in which Ming officialdom experienced diminishing stipends due to constantly rising grain prices. By positioning the Ming-Qing transition in global history, Wakeman suggests that the fall of the Ming 
and the rise of the Qing were part of much broader historical processes that included "the economic decline of seventeenth century commerce, the social disintegration of the Ming order, and the political consolidation of Qing rule" (p. 28). Interestingly, The Great Enterprise, Wakeman's celebrated masterpiece on the Manchu conquest, completely drops this global theme, and devotes its entire energy to the last two aspects of this dynastic transfer. Although these essays draw attention to Wakeman's global outlook, they need to be read against his major works, which do not indicate that this global framework was an overarching theme in structuring his historical writing, including his later scholarship on Shanghai.

4In fact, it may be suggested that Wakeman established himself as a historian of China with a strong emphasis on a local-centred if not China-centred approach. Wakeman's strength lay in his masterful command of historical narrative. In the last essay, entitled "Reflection" in reference to the ideal type of historical writing, Wakeman identifies the interpenetration of history and literature as the distinctive characteristic of great historical works. For Wakeman, the historian often meets in the middle ground with the novelist by blending together fancy and fact, fiction and history in historical narrative, while at the same time bringing analytical coherence into the multiplicity of historical voices through the reconstruction of a new structural totality. Wakeman quotes Hayden White to identify narrative as a unique kind of historical thinking advocated by a group of "historical thinkers without philosophical position who defended 'the craft notion of historical studies' and who 'view narrative as a perfectly respectable way of "doing" history-that is, the doxa of the profession" (p. 419). Wakeman declares that, it is with this kind of historical writing "I have identified myself most closely" (p. 419).

5Two essays in the volume on the Ming-Qing transition exemplify Wakeman's notion of doing history through the craft of "telling history." By writing on two of the most intriguing moments in Chinese history (the brief transitional period of the Sun Interregnum of 1644 in Beijing ruled by the rebellion leader Li Zicheng, and the Ming loyalists' defence of a local city in Jiangnan against the formidable Manchu conquest), Wakeman positions his works on the borderland between "wild histories" (yeshi) and "reliable" historical accounts, aiming to bring out from the historical narrative the maximum dual effects of historicity and historical validity. Interestingly, in its implicit questioning of Enlightenment ideas of scientific "History," Wakeman's literary and popularised notion of histories implicitly confirms what Frederic Jameson has described as the "cultural logic of late capitalism" in that it is a fictionalised history available for popular consumption and commodification. It is therefore no surprise to find in this essay that Wakeman highly praises Jonathan Spence's success as both an academic historian and a popular writer of history (p. 412). Within Wakeman's completely positive articulation and defence of this "historian's craft," his wholehearted embracing of this post-structuralist or post-modernist notion of "telling history" bypasses critical problems associated with the emergence of post-modernity.

6Essays in Part Five, "Modernity and State," recount Wakeman's strong interest in the relationship between the Chinese state and society. In "Chinese Archives and American Scholarship on Modern Chinese History," Wakeman reviews how the opening of Chinese archives in mainland China and Taiwan set the objective conditions for the emergence of the "new social history" among American scholars. For instance, based on the preliminary opening of the so-called "Canton Materials" captured by the British 
army during the opium wars, Wakeman's first book, Strangers at the Gate, built upon a common theme of militarisation of Chinese society by examining Chinese local responses to the onslaught of imperialism. In the early 1990s, the translation into English of Jurgen Habermas's The Structural Transformation of the Public Sphere (1989) and the field's enormous attention to local conditions generated a heated debate on the applicability of Habermas's concepts of "civil society" and "public sphere" to a distinct Chinese political and cultural context. Wakeman's position on the con side of the debate is clearly manifested in his article "Civil Society in Late Imperial and Modern China," included in this volume. This article sharply denounces William Rowe's acclamation of late Qing elite independent activism by arguing that the interpenetration of the state and social elites during the late Qing and early Republic made it difficult to clearly define a "civic power" against the state. As might be expected in light of his views on narrative, Wakeman was among the historians who questioned approaches that made modern European history into a universal standard of development, which was a problem he perceived in the idea of the "public sphere" that gained currency in response to the fall of socialisms in the 1980s. His work anticipated more recent scholarship that has shown a strong tendency to move beyond this highly charged question by suggesting the need to examine the historically specific configuration of the public in China in the late Qing and the early Republic, albeit not in a "China-centred" manner.

7Wakeman's interest in the Chinese state and society as the primary model of historical change further motivated him to study the modern Chinese police and their regulatory and disciplinary functions. The two articles in this volume on smuggling and prostitution in Shanghai survey Nationalist efforts from 1927 to 1949 to regulate these "vices of capitalism" in order to create a modern civic culture without "Western" materialistic and moral contamination. These articles later became the blueprint for Wakeman's monographs on the authoritarian if not fascist state in the 1930s, such as Policing Shanghai and The Shanghai Badlands. By stepping into the underground world of gambling, opium smoking, and smuggling, prostitution, and other "unhealthy" elements of the entertainment industry, Wakeman's essays on policing introduced subaltern issues into the new social history. More crucially, situated in a colonial urban setting (particularly modern Shanghai), the study of the Chinese subaltern implicitly connected the new social history to the new cultural history with a particular focus on culture and modernity. Wakeman's essays and his monographs played a leading role in the emergence and the later dominance of "Shanghai Studies" in the field, stimulating further work on the formation and transformation of (semi)colonial urban culture, issues of cultural and social identity-particularly for urban women-and the spread of commercial and popular culture. This new paradigmatic change designated modernity and globalisation as prominent topics of research on modern China and accordingly rendered socialism and revolution into outdated modes of thought and practice. "Shanghai Studies" also articulated the ideological shift accompanying China's embrace of globalisation, and the consequent marginalisation of the revolutionary past.

8The collection gives readers a useful introduction to the wide-ranging interests of a distinguished scholar. The 15 essays together recapture the three main areas of Wakeman's scholarship that had a significant impact on the field of Chinese studiesthe Ming-Qing transition, the relationship between the Chinese state and society, and "Shanghai studies." Often produced at the same time as his monographs, these essays especially give insight into the connected but shifting intellectual interests that led to 
the production of Wakeman's major scholarship. For this reason, this volume is a valuable addition to Wakeman's well-known monographs. Moreover, for those who are interested in Wakeman's China career, the volume also offers some interesting glimpses into his personal, educational, and political experiences with a multiple-faced china during its four decades of transformation. 